Article

\title{
Biomass Carbon Sequestration Potential by Riparian Forest in the Tarim River Watershed, Northwest China: Implication for the Mitigation of Climate Change Impact
}

\author{
Tayierjiang Aishan ${ }^{1,2}$ (1) , Florian Betz ${ }^{3}$, Ümüt Halik $^{2, *}$, Bernd Cyffka ${ }^{3}$ (i) and \\ Aihemaitijiang Rouzi ${ }^{2}$ \\ 1 Institute of Arid Ecology and Environment, Xinjiang University, Sheng Li Road 666, Urumqi 830046, \\ Xinjiang, China; tayirjan@xju.edu.cn \\ 2 Key Laboratory of Oasis Ecology, College of Resources \& Environmental Sciences, Xinjiang University, \\ Sheng Li Road 666, Urumqi 830046, Xinjiang, China; ahmadjan_1983@yahoo.com \\ 3 Faculty of Mathematics and Geography, Catholic University of Eichstaett-Ingolstadt, Ostenstraße 14, \\ 85071 Eichstatt, Germany; florian.betz@ku.de (F.B.); bernd.cyffka@ku.de (B.C.) \\ * Correspondence: halik@xju.edu.cn; Tel.: +86-189-9911-1553
}

Received: 14 February 2018; Accepted: 3 April 2018; Published: 10 April 2018

\begin{abstract}
Carbon management in forests has become the most important agenda of the first half of the 21st century in China in the context of the mitigation of climate change impact. As the main producer of the inland river basin ecosystem in arid region of Northwest China, the desert riparian forest maintains the regional environment and also holds a great significance in regulating the regional/global carbon cycle. In this study, we estimated the total biomass, carbon storage, as well as monetary ecosystem service values of desert riparian Populus euphratica Oliv. in the lower reaches of the Tarim River based on terrestrial forest inventory data within an area of 100 ha (100 plots with sizes of $100 \mathrm{~m} \times 100 \mathrm{~m}$ ) and digitized tree data within 1000 ha (with $10 \mathrm{~m} \times 10 \mathrm{~m}$ grid) using a statistical model of biomass estimation against tree height (TH) and diameter at breast height (DBH) data. Our results show that total estimated biomass and carbon storage of P. euphratica within the investigated area ranged from 3.00 to $4317.00 \mathrm{~kg} / \mathrm{ha}$ and from 1.82 to $2158.73 \mathrm{~kg} / \mathrm{ha}$, respectively. There was a significant negative relationship $(p<0.001)$ between biomass productivity of these forests and distance to the river and groundwater level. Large proportions of biomass (64\% of total biomass) are estimated within $200 \mathrm{~m}$ distance to the river where groundwater is relatively favorable for vegetation growth and biomass production. However, our data demonstrated that total biomass showed a sharp decreasing trend with increasing distance to the river; above $800 \mathrm{~m}$ distance, less biomass and carbon storage were estimated. The total monetary value of the ecosystem service "carbon storage" provided by P. euphratica was estimated to be $\$ 6.8 \times 10^{4}$ USD within the investigated area, while the average monetary value was approximately $\$ 70$ USD per ha, suggesting that the riparian forest ecosystem in the Tarim River Basin should be considered a relevant regional carbon sink. The findings of this study help to establish a better understanding of the spatial distribution pattern of $P$. euphratica forest under water scarcity and can also provide an alternative approach to local decision-makers for efficient and precise assessment of forest carbon resources for emission reduction programs.
\end{abstract}

Keywords: river discharge; groundwater level; riparian forest; climate change; watershed management 


\section{Introduction}

Terrestrial ecosystem biomass is a basic quantitative characteristic of an ecosystem and also a major ecological parameter in determining carbon sequestration and carbon sink function. Among the numerous types of ecosystems, forest ecosystems play a crucial role in the global carbon budget [1-6]. In Central Asia, desert riparian forest ecosystems along large river systems, such as the Amu Darya, Syr Darya, and Tarim River, store a large amount of carbon in the aboveground (leaves, branches, and stems) and belowground (roots) biomass and provide the main biomass resources for human wellbeing in those continental arid regions [7-11]. Due to the extremely arid climate conditions of these regions, the productivity of riparian forest ecosystems is highly dependent on groundwater and soil moisture availability supplied by inland river water flow [12]. Therefore, it is crucial to understand the relationship between hydrological regime, ecological development, and resource management in order to apply a forest management that is able to sustain the biomass budget and carbon storage of floodplain forests in those regions.

The Tarim River, located in the arid region of the Northwest China, is one of the largest inland rivers in the world along with the Volga, Syr Darya, Amu Darya, and the Ural [13]. It is mainly supplied by glacier and snow melt water and precipitations from the Tian Shan Mountains. Desert riparian forests distributed along the river are extremely important natural barriers supporting the ecological stability of the region. Populus euphratica Oliv. is the dominant tree species of Tugai vegetation (composed of trees, shrubs, and herbals) in the extremely dry areas of Central Asia and forms the main biomass reservoir and natural carbon sink in the Tarim River Basin [10,11]. More than 90\% of existing floodplain forests along the Tarim River are P. euphratica riparian forests [14,15].

Carbon storage is one of the major ecosystem services provided by the Tugai forests in addition to the reduction of sand and dust storms, moderation of desertification, and regulation of oasis climate [16,17]. Reduction of $\mathrm{CO}_{2}$ in the atmosphere helps mitigate climate change through its various effects and, therefore, is an important contribution to peoples' well-being [1]. Tarim riparian forests, in contrast to China's other forests, are characterized by their patchy distribution, high carbon (C) density, and high anthropogenic disturbance and they function as an important carbon pool in China's northwest arid region.

Over the past 50 years, however, due to climate change and the rapid socio-economic development in Xinjiang (especially increasing water demands for cotton production), many tributaries of the watershed were disconnected from the Tarim River $[18,19]$. The water discharge in the main stream of the Tarim River has dramatically decreased. More seriously, more than $320 \mathrm{~km}$ of river channel along the lower reaches of the Tarim River were completely desiccated since the construction of Daxihaizi reservoir in 1973. Consequently, the groundwater level dropped to 10-12 m below the surface and became salinized [20-24]. As a result of ecosystem deteriorations, substantial amounts of carbon stored in this riparian vegetation have been lost due to the reduction in the amount of live biomass.

In response to the aforementioned environmental damage, the Chinese government invested $10.7 \times 10^{8} \mathrm{RMB}$ (approx. $\$ 1.8$ billion USD) in the implementation of the "Integrated Water Resource Management of the Tarim River Basin" program to secure the ecological, economic, and social sustainability of the oases along the Tarim River [20]. The ecological water diversion project (EWDP) is one of the key sub-projects within this restoration program; it started in May 2000 and was implemented in the lower reaches of the Tarim River with multiple purposes ranging from regenerating degraded riparian forests to improving environmental conditions and maintaining the green corridor for economic development $[20,25,26]$. Accompanying the restoration project, the majority of the research mainly focused on the responses of the groundwater table and various eco-physiological and morphological parameters of riparian forests to the rehabilitation measures [20,21,26-30], but relative research about the quantification of the live biomass structure and carbon storage potential of P. euphratica desert riparian vegetation in the lower reaches of the Tarim River had not been reported. Understanding the biomass structure of P. euphratica forest and its spatial distribution under ongoing ecological restoration practices is needed for estimating the contributions of these forests to mitigate 
climate change impacts in the region. The main objectives of this study are to estimate the spatial variability of biomass productivity and capacity of carbon sequestration by desert riparian P. euphratica forest and to monetize its carbon storage ecosystem service. This study is expected to broaden our understandings on biomass carbon distribution patterns under the current restoration program in this region and to facilitate riparian restoration by increasing awareness of decision makers on the potentials of desert riparian forests to sequester carbon. Research findings would provide a scientific basis for evaluating the contribution of riparian ecosystem to climate change mitigation through sustainable management of water resources (allocation of substantial water for ecology) and riparian forests (facilitating rehabilitation of highly-degraded vegetation).

\section{Materials and Methods}

\subsection{Study Area Description}

The study area is situated at Arghan village $\left(40^{\circ} 08^{\prime} 50^{\prime \prime} \mathrm{N}, 88^{\circ} 21^{\prime} 28^{\prime \prime} \mathrm{E}\right)$, between Taklimakan and Kuruk Tag desert, in the lower reaches of the Tarim River, Xinjiang Uyghur Autonomous Region, Northwest China (Figure 1). This area is located in an extremely arid climatic zone with an annual precipitation <15 mm (Figure 2) and potential annual evaporation of 2500-3000 mm [14,20,27,31]. Sparse vegetation is predominantly distributed on the river floodplain ecosystem. It comprises trees, shrubs, and herbs. P. euphratica is the dominant species. Nearly $70 \%$ of the existing species in our study area are of P. euphratica [32]. Shrubs include Tamarix ramosissima Ledeb., Tamarix hispida Willd., Tamarix elongata Ledeb., Lycium ruthenicum Murr., Halimodendron halodendron (Pall.) Voss., Halostachys caspica (M.B.) C.A. Mey., Poacynum hendersonii (Hook. F.) Woodson., Alhagi sparsifolia (B. Keller et Shap.) Shap., Glycyrrhiza inflata Bat., Karelinia caspica (Pall.) Less., Inula salsoloides (Turcz.) Ostrnf., and Hexinia polydichotoma (Ostent.) H.L. Yang [10,20,21]. Besides Tamarix, most shrubs and herbs are distributed within the range of $100 \mathrm{~m}$ from the river. In particular, due to the scarcity of precipitation, groundwater is the main source of water that is required to maintain the structure and functions of riparian ecosystem in this hyper-arid region. In addition, this ecosystem is highly vulnerable to climate change. The river flow in the lower reaches of the Tarim River is complex and is comprised of many intersections and meanders. The river bed divides into two branches at $4.2 \mathrm{~km}$ downstream from the Daxihaizi reservoir. The western branch is the old Tarim River and the eastern branch is the Qiwinkol River. The two branches are roughly parallel to one another and converge at Arghan, where vegetation coverage is relatively high and the anthropogenic impacts, such as grazing and fuel wood harvest on the sampling sites, are not intensive. Therefore, Arghan is an ideal location for the estimation of tree biomass and carbon storage and their spatial distribution under current ongoing water diversion practices. In addition, six groundwater gauges installed there by the Tarim River Basin Management Bureau enable long-term monitoring of groundwater level changes.

\subsection{Data Collection and Processing}

The assessments of biomass and carbon storage presented in this study were performed by three steps (Figure 3). In a first step, biomass was estimated for a total number of 4773 P. euphratica tree stands within 100 ha monitoring plots (Figure 4). For the biomass estimation, we used allometric formulas suggested by Chen and $\mathrm{Li}$ [33]. These formulas link diameter at breast height (DBH), tree height, and biomass and have already been successfully applied to similar study regions at the middle/lower reaches of the Tarim River [10,34] and at the Amu Darya in Turkmenistan [10,11]. The parameters have been measured for the permanent monitoring plots within the growing season in 2010 and 2011. The DBH of each tree was measured with a DBH meter and tree height was determined with a laser distance meter. 


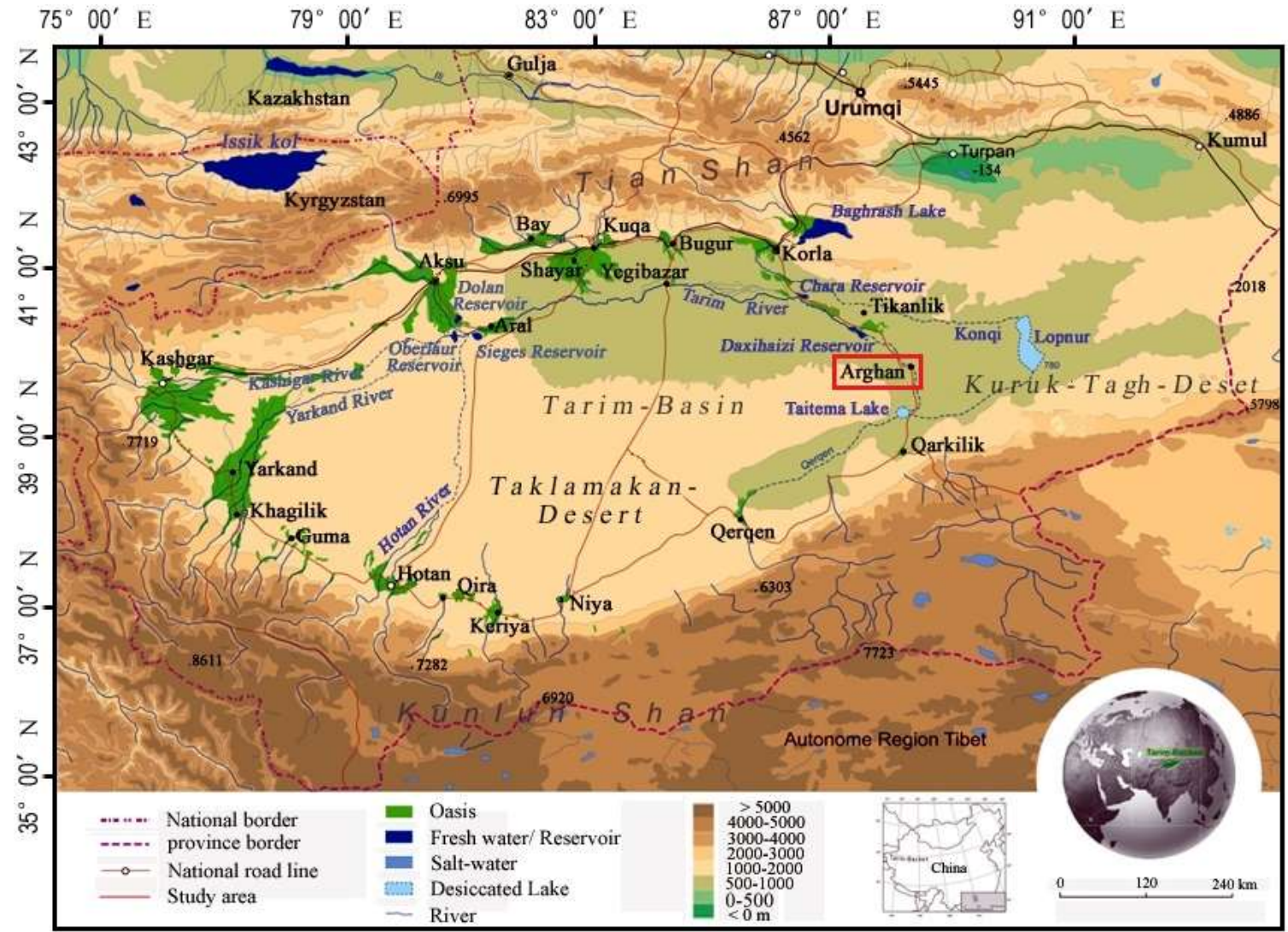

Figure 1. Locations of the lower reaches of the Tarim River and the Arghan transects.

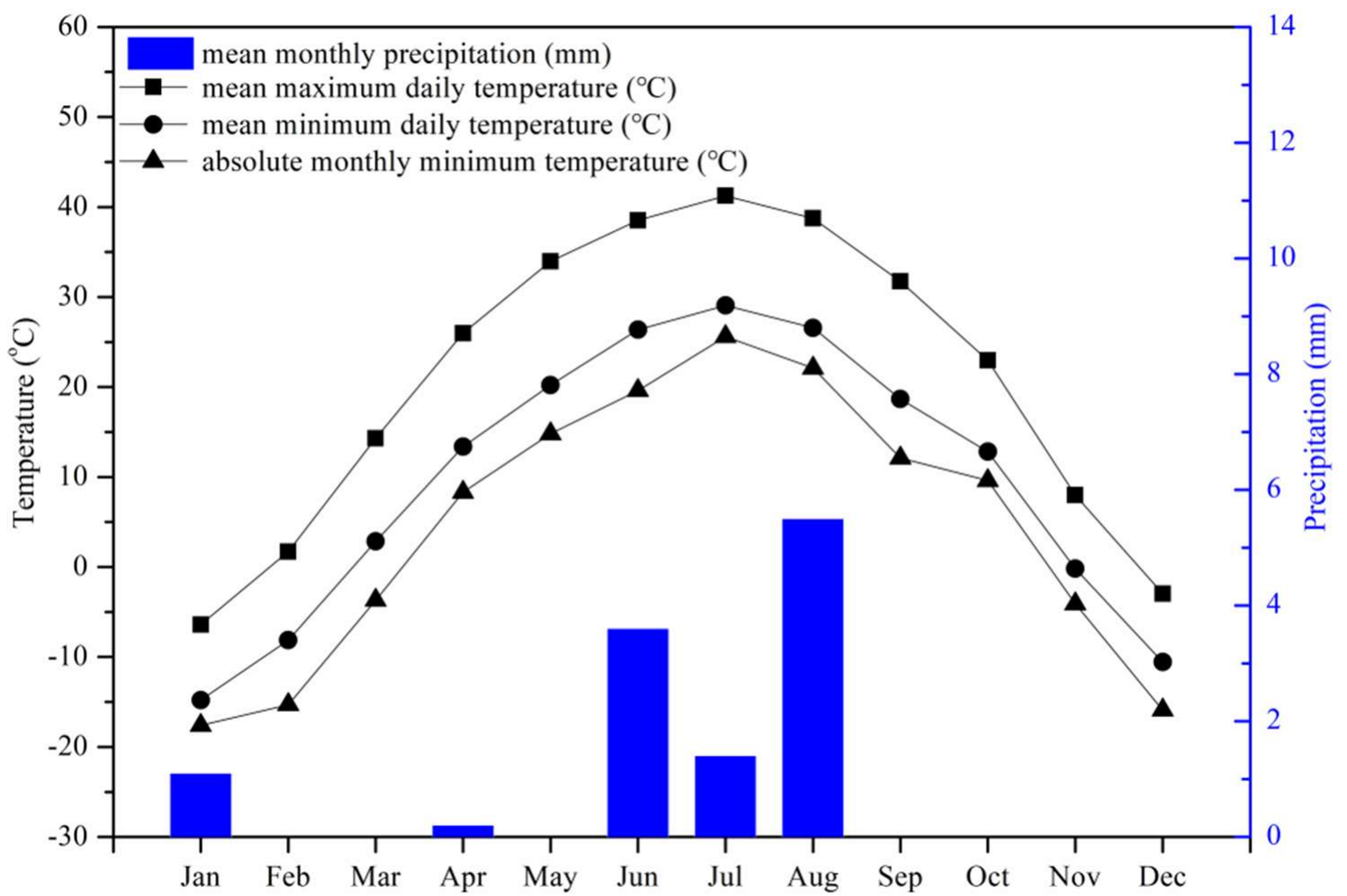

Figure 2. Climate diagram of the study area (based on data from Arghan for the period from 2013 to 2015). 


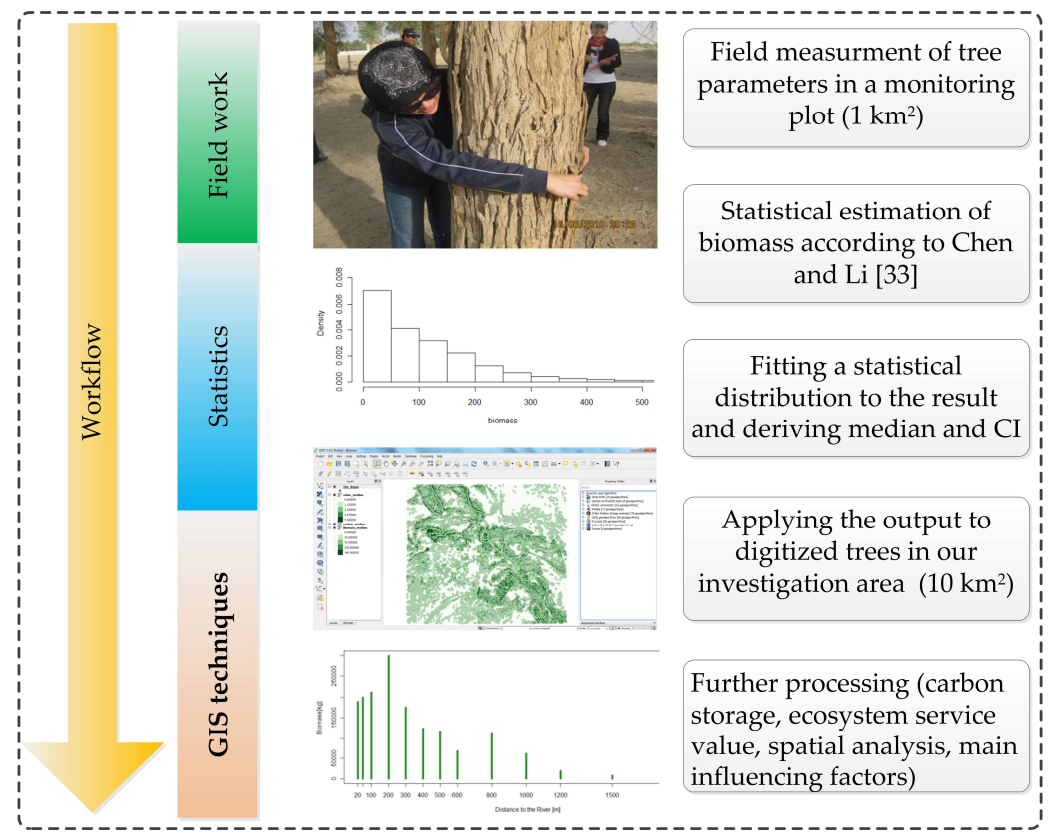

Figure 3. The workflow of this study (CI indicates confidence interval, GIS techniques refers to some of geographical information system tools such as digitization used in this study).

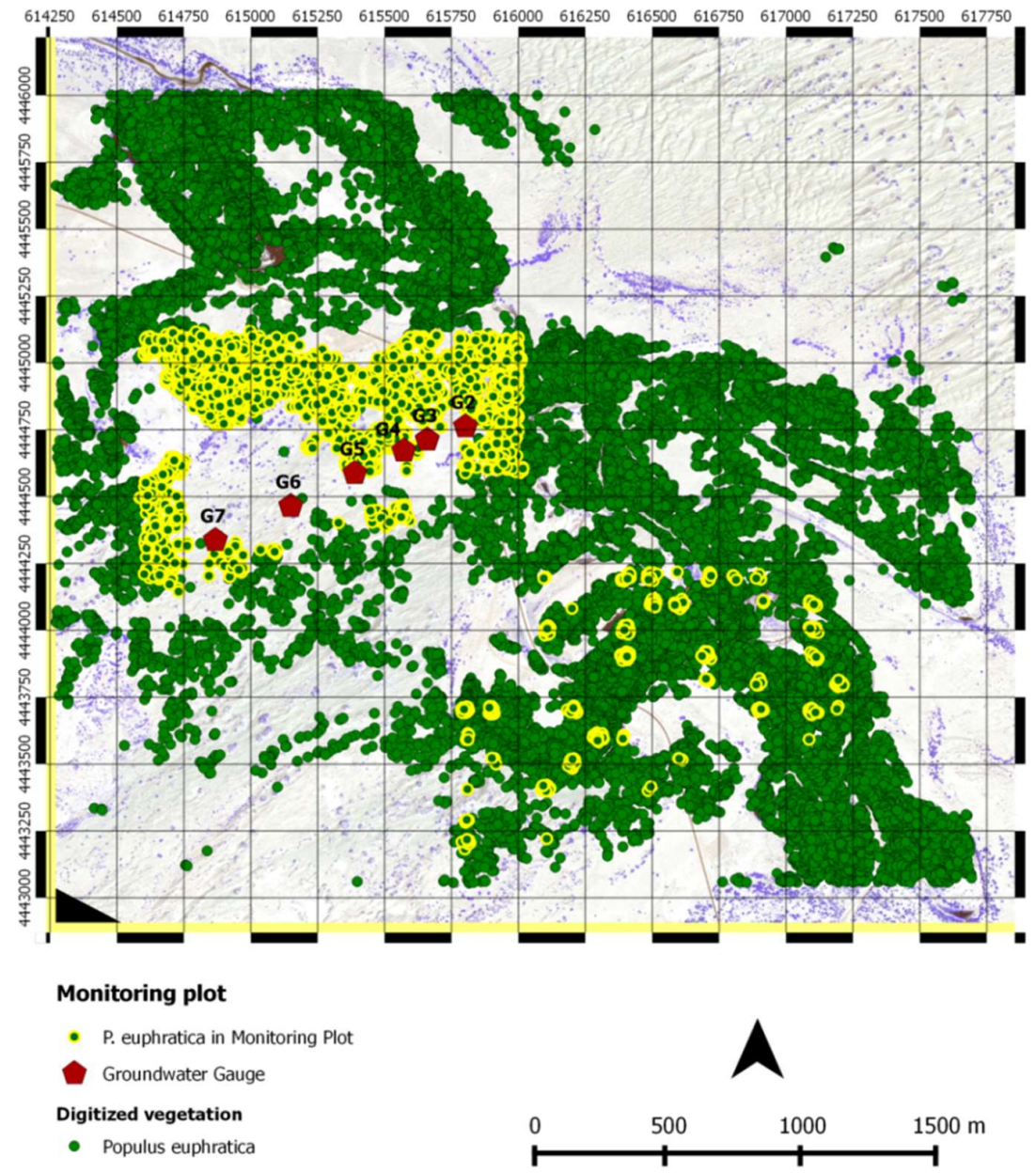

Figure 4. Data used for the biomass estimation of $P$. euphratica. 
Once the allometric parameters were obtained for each tree in the monitoring plots, we calculated the biomass for each single tree using the formulas of Chen and Li [33] given in Table 1. Then, we fitted a statistical distribution to the tree biomasses. Due to the right-skewed nature of the empirical distribution, we chose the Weibull distribution, a widely-used theoretical distribution for analyzing the environmental data (Equation (1)):

$$
\mathrm{F}(x)=1-\exp ^{-(\lambda x)^{\mathrm{k}}}
$$

where $\lambda$ is the scale factor and $k$ the shape factor. For the fitting procedure, we used the maximum likelihood method, as suggested by Venables and Ripley [35]. This distribution was used to calculate the boundaries of the $95 \%$ confidence interval (CI), as well as the median of the biomass.

Table 1. Formulas of Chen and $\mathrm{Li}$ [33] for the relationship between the diameter at breast height (DBH) in centimeters, the tree height $(\mathrm{H})$ in meters, and the biomass in kilograms.

\begin{tabular}{ccc}
\hline Biomass Fraction & Formula & Correlation Coefficient R \\
\hline Trunk biomass (BT) & $\operatorname{LogBT}=\log 0.0382+0.8837 \times \log \mathrm{DBH}^{2} \mathrm{H}$ & 0.99 \\
Branch and twig biomass (BB) & $\operatorname{LogBB}=\log 0.1072+0.6350 \times \log \mathrm{DBH}^{2} \mathrm{H}$ & 0.89 \\
Leaf biomass (BL) & $\log \mathrm{BL}=\log \left(1.41 \times 10^{-3}\right)+0.8134 \times \log \mathrm{DBH}^{2} \mathrm{H}$ & 0.71 \\
Root Biomass(BR) & $\mathrm{LogBR}=\log 0.1059+0.6185 \times \log \mathrm{BBH} \mathrm{H}^{2} \mathrm{H}$ & 0.94 \\
Total Biomass (B) & $\mathrm{B}=\mathrm{BT}+\mathrm{BB}+\mathrm{BL}+\mathrm{BR}$ & \\
\hline
\end{tabular}

Since the monitoring plots cover the most representative environmental situations for the study area, we assumed that the distribution could represent all possible tree biomass values occurring within the environmental setting. Thus, we used the $95 \%$ confidence intervals of the Weibull distribution to estimate the possible range of biomass for each P. euphratica tree in the study area. All euphratica poplars in the study area were digitized from a QuickBird satellite image with a resolution of $0.5 \mathrm{~m}$. The trees could be clearly distinguished from other shrub-like species via the visible crown shadow by naked eye. Then, the minimum, maximum, and median of the biomass values obtained from the fitted Weibull distribution were assigned to the approximately 23000 points representing the poplars in the study area (Figure 4). Then, the point values for biomass were transferred into a $10 \mathrm{~m} \times 10 \mathrm{~m}$ raster using the sum of all biomass values as cell value. In a subsequent step, the biomass values were transferred to carbon storage values by using a converting factor of 0.5 , as suggested by the Intergovernmental Panel on Climate Change (IPCC) [1]. When the specific C content is unknown, different researchers have estimated $C$ content as $50 \%$ of the absolutely dry mass of the stem, roots, and leafless branches [36]. For the calculation, we focused on the median of the biomass. This is, of course, a rough estimate only. Nevertheless, along with the $95 \%$ confidence interval, this approach gives a reliable range of biomass and associated carbon storage values of P. euphratica for the study area at the lower reaches of the Tarim River. However, further research is needed to reduce uncertainties.

To obtain the relationship with water availability, the main ecological driver of the study area, a buffer analysis was carried out for zones $100 \mathrm{~m}$ from the river. This reflects the assumption that the water supply is controlled by the river only, which is a rational assumption for a region with an annual precipitation of below $15 \mathrm{~mm}$. For further analysis, the values of biomass and carbon storage of the raster dataset were extracted. Then, the sum of all cell values were calculated to obtain the biomass or carbon storage for a certain distance range from the river.

The final step was to valuate the carbon storage of $P$. euphratica as an ecosystem service. The approach chosen was to consider avoided economic damage assuming that the storage of carbon avoids the emission of $\mathrm{CO}_{2}$ and, therefore, reduces the effect of climate change with its negative social and economic consequences. The monetary value of these consequences is also known as the social costs of carbon. Several well-known studies have been conducted for estimating these costs, for example, the Stern Report [37]. Tol [38] combined the results from 232 published estimates for the value of social costs of carbon and reported a median value of $87 \mathrm{USD} / \mathrm{t} \mathrm{C} \mathrm{[38].} \mathrm{The} \mathrm{value} \mathrm{determined}$ 
by Tol [38] was also used for the social costs of carbon in this paper. This avoided damage approach has been widely used in multiple settings, such as in Integrated valuation of ecosystem services and tradeoffs (InVEST) model [39]. However, this approach is not without its criticisms [40,41] and other methods, like using prices from carbon markets, are also available [42], with most methods suffering some flaws in their valuation due to market's inadequacy at capturing all the externalities and different accounting systems being used. Thus, the economic valuation presented in this study is one possible criterion to assess monetary values of carbon in order to provide references to policy-makers, even though it still has some drawbacks.

\section{Results and Discussions}

\subsection{Spatial Distribution of Biomass, Carbon Storage, and Ecosystem Service Value}

Estimation of biomass carbon storage of P. euphratica forest is complex due to both temporal and spatial variability, which result from the variation in individual growth patterns. These factors, along with water availability (groundwater and soil moisture), micro-topography, and salt placement, lead to a non-uniform/heterogeneity in biomass distribution in our study area. Currently accepted methods for biomass estimation of many other forest types assume a normal distribution. In this study, this assumption turned out not to be tenable. As such, in this study, Weibull distribution was fitted to a model of the distribution of P. euphratica biomass. The fitted Weibull distribution to the biomass of the monitoring plot is shown in Figure 5. This curve is clearly positively skewed, which indicates that trees with a low biomass have a much higher probability to occur than trees with a high biomass. From this, the $95 \%$ confidence intervals of $1.17 \mathrm{~kg}$ for the lower boundary and $544.62 \mathrm{~kg}$ for the upper boundary, as well as the median of $69.36 \mathrm{~kg}$, were calculated.



Figure 5. Weibull distribution fitted to the biomass values of P. euphratica within the monitoring plot.

These values (Table 2) have been assigned to the tree-points in Quantum GIS (QGIS) and summarized. Results show that the median value of biomass was $1,581,166 \mathrm{~kg}$, which means $790,583.20 \mathrm{~kg}$ of stored carbon and a resulting ecosystem service of $\$ 68,780.74 \mathrm{USD}$. In addition to the absolute results, there was a clear spatial distribution pattern of biomass within the investigation area (Figure 6). Maximum values of biomass were found to concentrate close to the river channel or old river branches, while it values tended to decrease with increasing distance to the river. This phenomenon could be explained by the productivity and reproduction strategy of P. euphratica, which is heavily dependent on flooded areas and freshly-sedimented river banks [10,34,43]. Detailed analyses for this distribution were carried out by a buffer analysis with different distances to the river (Figures 7 and 8). The highest values for biomass, carbon storage, and ecosystem service values occurred within $200 \mathrm{~m}$ of the river. Within this zone, $20,915 \mathrm{~kg} / \mathrm{ha}$ of biomass were stored, which accounted for $64 \%$ of the total value in the investigation area. In the distance of $200 \mathrm{~m}$ to $800 \mathrm{~m}$ only slight differences occurred. 
Within this area, another $31 \%(6446 \mathrm{~kg} / \mathrm{ha})$ of the biomass was stored. Above a distance of $800 \mathrm{~m}$ the biomass decreased sharply and reached a level of zero greater than $2000 \mathrm{~m}$ from the river.

Table 2. Results from the estimation of biomass, carbon storage, and the value as an ecosystem service for the whole investigation area.

\begin{tabular}{cccc}
\hline & Lower Boundary of CI & Median & Upper Boundary of CI \\
\hline Biomass & $26,737.29 \mathrm{~kg}$ & $1,581,166 \mathrm{~kg}$ & $12,416,286 \mathrm{~kg}$ \\
Carbon Storage & $13,368.64 \mathrm{~kg}$ & $790,583.20 \mathrm{~kg}$ & $6,208,143 \mathrm{~kg}$ \\
Value & $1163.072 \$$ & $68,780.74 \$$ & $540,108.4 \$$ \\
\hline
\end{tabular}

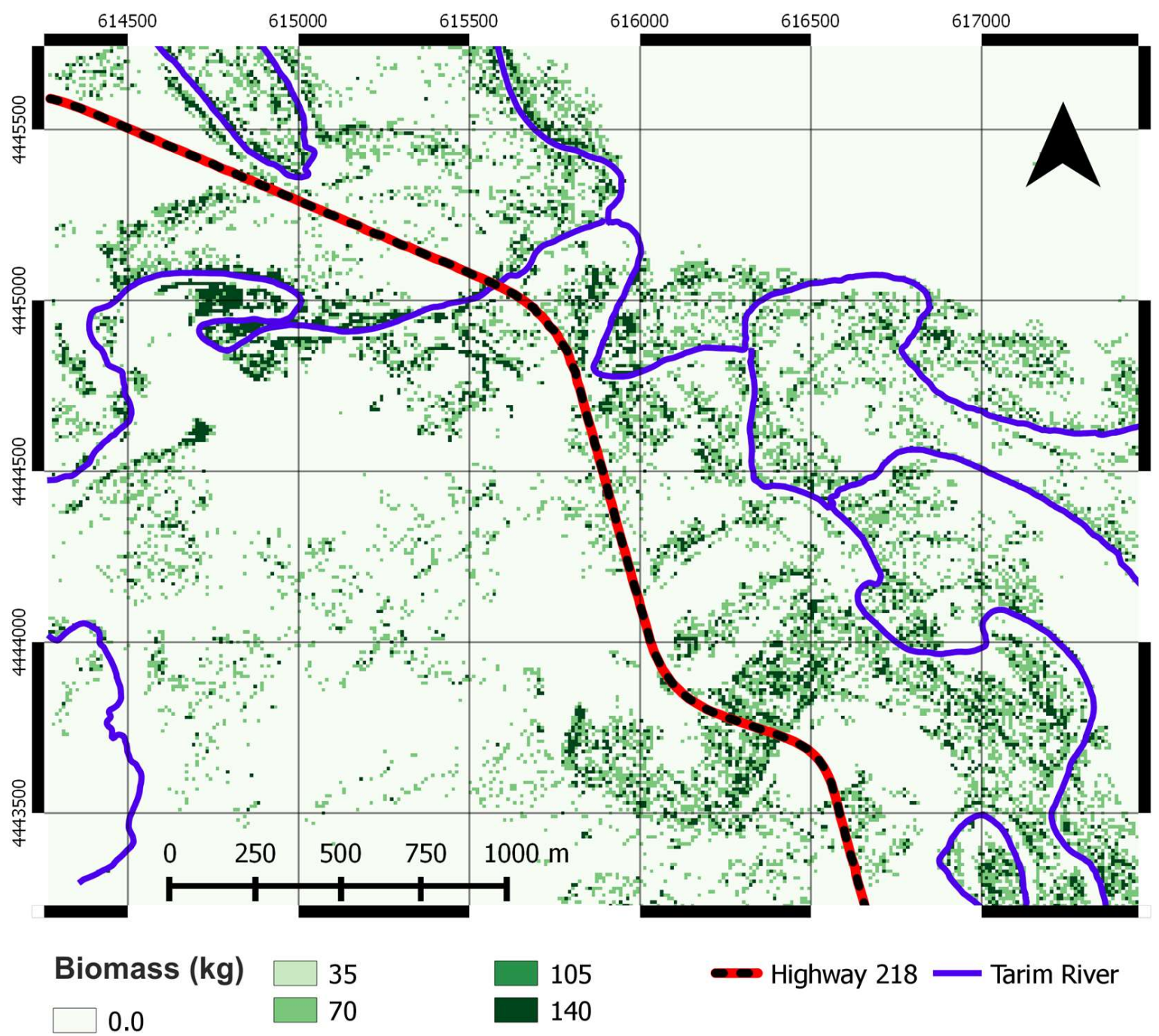

Figure 6. Spatial distribution of estimated potential biomass distribution for P. euphratica forests at Arghan in the lower reaches of the Tarim River. 




Figure 7. Biomass, carbon storage, and value of ecosystem service of P. euphratica forests at different distances from the river.



(a)

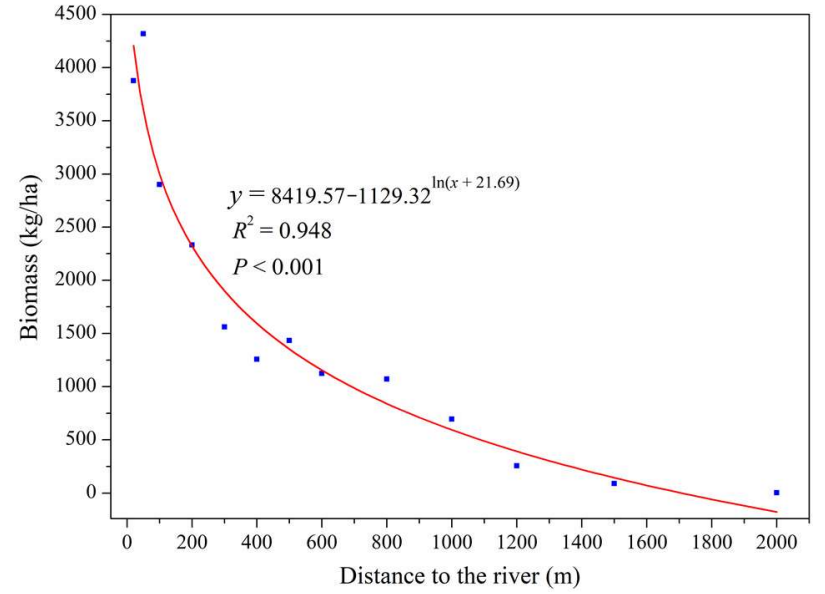

(b)

Figure 8. Biomass distribution pattern of $P$. euphratica along a gradient of water stress. (a) Biomass estimation in different buffer zones from the river; and (b) the relationship between biomass and distance from the river.

\subsection{Dependency of Tree Biomass Production and Carbon Storage on Water Availability}

There are many environmental factors influencing biomass production of riparian forest, such as climate, water availability, topographical conditions, and age structures of riparian vegetation [44-46]. As we pointed out above, nearly 30 years of river desiccation in the lower reaches of the Tarim River resulted in the decline of groundwater and massive destruction and degradation of natural vegetation along both sides of the river channel, which led to a lasting decrease in the carbon storage of riparian vegetation, with an increased accumulation of dead wood. Due to extremely harsh environmental conditions, riparian forests in the lower reaches of the Tarim River mainly depend on the limited groundwater to sustain their life cycle. As shown in Figure 8a, estimated tree biomass presented 
different values within different buffer zones from the river. Furthermore, we used regression analysis to analyze the correlation between biomass and distance to the river (Figure $8 b$ ) and found that there was a negative correlation between the biomass of $P$. euphratica forest and distance from the river; the determination coefficient was greater than 0.9 and the correlation is significant $(p<0.001)$. Within $20 \mathrm{~m}$ distance from the river, total tree biomass was estimated to be about $4000-5000 \mathrm{~kg} / \mathrm{ha}$, while $3000-4000 \mathrm{~kg} / \mathrm{ha}$ of tree biomass was distributed within the area $20 \mathrm{~m}$ to $100 \mathrm{~m}$ from the river. Above $100 \mathrm{~m}$ distance from the river, less biomass was estimated and the amount of biomass decreased dramatically with increasing distance from the river channel. To the direction of desert margin, almost no biomass was found. Groundwater in arid regions of Central Asia is one of the decisive factors for promoting carbon sequestration capacities of the floodplain forests $[10,11,34]$. Figure 9 shows that there were obvious differences between groundwater levels at different distances to the river. Generally, groundwater levels were closely related to the distance from the river. With increasing distance to the river channel, groundwater levels also presented a decreasing trend. Trees growing under favorable groundwater conditions have healthy and large crowns with dense foliage, which contributes to an increase of above-ground biomass.

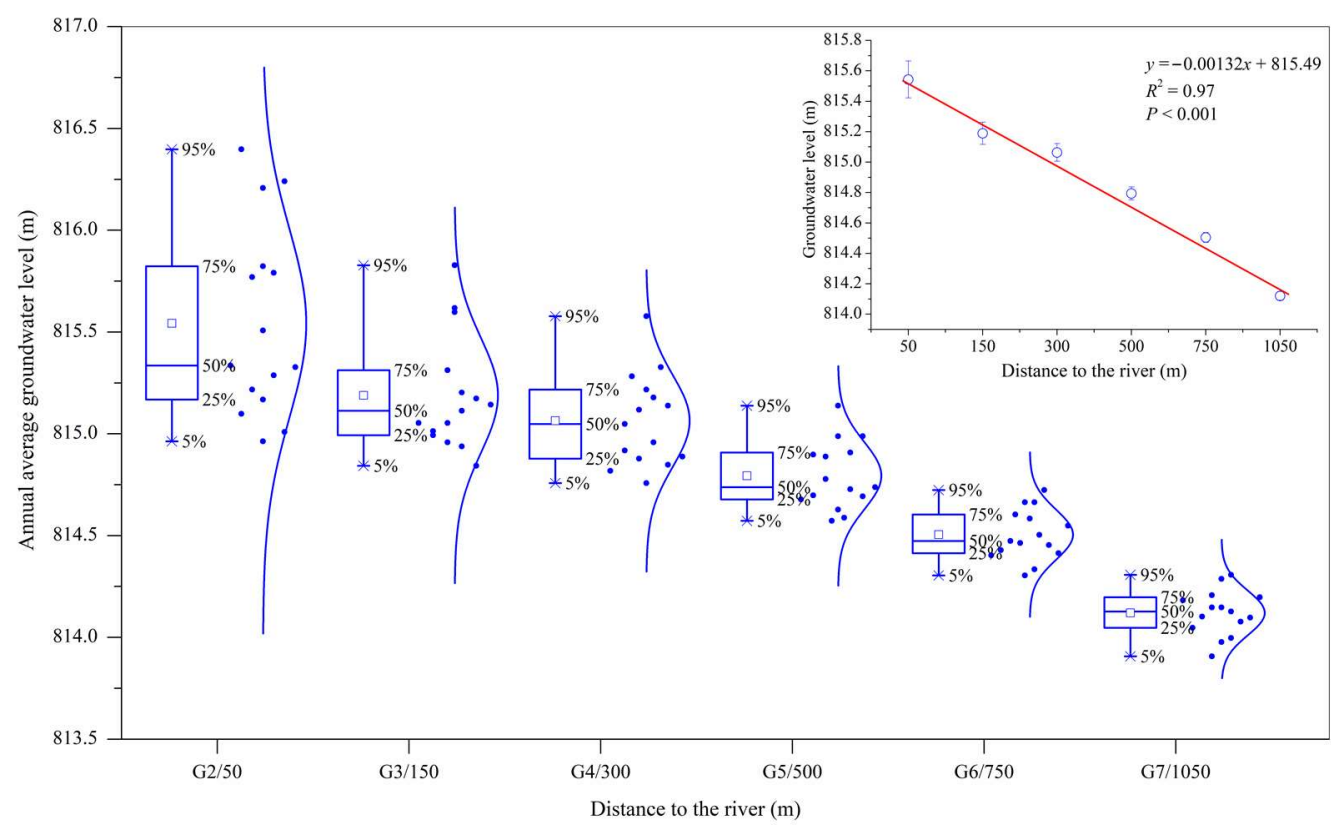

Figure 9. Groundwater levels at different distances to the river (G refers to the name of the groundwater monitoring well; see also Figure 4).

The zone far away from the river is characterized by a harsh environment due to highly limited water resources. Thus, normal growth of P. euphratica trees is prohibited, leading to less biomass production. At present, water diversion practices are the main environmental driver for eco-hydrological processes of the riparian ecosystem in the region. Seventeen water diversions in the lower reaches of the Tarim River have played a significant role in raising groundwater tables near to the main river course and in recovering floodplain forests to a certain degree $[30,47,48]$. On the other hand, these practices might be a major contributor for producing a higher biomass by means of improving water availability and leading to the sequestration of carbon. However, some studies also indicated that current water diversion practices are less effective for the large-scale establishment of new seedlings and juvenile trees [20,49]. It was observed that young forests have greater annual carbon sequestration rates while mature forests store more carbon [5]. Therefore, much effort should be carried out to create suitable habitat conditions for maintaining the current carbon storage and increasing the carbon sequestration capacities of riparian forests by changing their age. 


\subsection{Potential Effect of Water Diversion Project in Relation to Forest Carbon Storage}

By the end of 2015, ecological water was diverted 17 times in irregular frequencies throughout 1714 days in 16 years with a total volume of $51.10 \times 10^{8} \mathrm{~m}^{3}$. As mentioned above, ecosystem services of desert riparian forests in the lower reaches of the Tarim River are highly controlled by water availability (particularly groundwater). Thus far, other important benefits of the water diversion project, such as increasing carbon sequestration potentials of desert riparian forests, have rarely been reported or mentioned. These benefits are mainly reflected in two aspects: (i) promoting the growth and recovery of the vegetation by satisfying its water requirement; and (ii) establishing more young seedlings and juveniles by increasing the overflow area of water delivery. Here, we mainly discuss the potential effects of water diversion projects on actual carbon storage and future carbon sequestration and how these particular ecosystem services could be improved by water management. Specifically, we examined how water availability (groundwater level and soil moisture) affects the distribution of biomass carbon storage of P. euphratica riparian forest.

The growth of desert riparian forest is dependent on the groundwater level, which is determined by the amount, duration, and magnitude of the current water diversion project in the region $[32,34,50]$. Furthermore, sufficient soil moisture, even though it has a limited effect on adult trees (e.g., Populuseuphratica.) and shrubs (e.g., Tamarix spp.), is also a key factor that must be considered, since it activates the soil seed bank, sustains herbs and shrubs with shallower root systems, and creates favorable habitat conditions for the establishment, survival, and growth of P. euphratica young seedlings. However, in our research area, high densities of P. euphratica seedlings mainly occurred in the vicinity of the zones that are highly affected by water diversions or around suitable micro-relief [20]. Hao and $\mathrm{Li}$ [50] found that changes in groundwater depth also led to corresponding changes of groundwater quality and soil moisture. Without a doubt, increased delivery of water in sufficient duration and magnitude into the downstream is highly desirable, since it is the only driver for rehabilitating degraded riparian ecosystems and producing more biomass. Hence, the amount and time of ecological water diversion need to be ensured according to the eco-hydrological requirements of riparian vegetation so that the capacity of carbon sequestration potentials in the desert riparian forest in the Tarim River Basin can be improved and maximized. However, water use conflicts between water demand and supply along the entire river basin and overexploitation of water in the upper and middle reaches of the river are still challenging [51].

In view of the above, increasing the carbon storage of $P$. euphratica forest through ecological water conveyance may be the most effective option to reduce the rise of atmospheric carbon dioxide concentration in the region. Numerous studies have quantified regulated ecosystem services of riparian forests along the lower reaches of the Tarim River by using an ecosystem service accounting method and the results of these studies highlighted the importance of water diversion effects on the carbon sequestration potentials of degraded riparian forests [16,52,53]. Currently, the impact of ecological water conveyance on the recharge of groundwater is very significant. In recent years, the suitable groundwater levels for the desert riparian forests have been achieved to some extent in the lower reaches of the Tarim River via the implementation of water diversions on 17 separate occasions [54]. From this point of view, our study implies that large-scale ecological restoration programs, such as rehabilitation and restoration of riparian forests by water diversion, could help to enhance regional/global carbon sinks, which may shed new light on the carbon sequestration benefits of such programs in the arid regions of Northwest China and also in other regions.

In the present study, we mainly focused on the quantification of P. euphratica forest biomass carbon, since it is a predominantly distributed species along the Tarim River. However, there are knowledge gaps regarding properties, processes, and practices affecting carbon sequestration in soil, deadwoods, and other vegetation (e.g., shrubs and herbs) that must be filled in order to develop a comprehensive sustainable forest management program along the lower reaches of the Tarim River. 


\subsection{Implications of the Results for Climate Change Mitigation}

According to an IPCC report, various afforestation and reforestation efforts could reduce global atmospheric $\mathrm{CO}_{2}$ by $25 \%$ by 2020 [55]. Reducing Emissions from Deforestation and Forest Degradation (REDD) and the Clean Development Mechanism (CDM) have been used in developing countries to promote low carbon paths to sustainable development [56]. China has developed its own pilot emission trading system (ETS) where Chinese Certified Emission reduction projects to trade carbon credits in the eastern provinces [57]. Although Xinjiang has not officially participated in the pilot project yet, a soon to be implemented nation-wide policy would provide the region more opportunities to trade its carbon credits with more developed regions on the coast. Water diversion-induced carbon accumulation would be an attractive alternative for emission trading, and achieving restoration of the degraded ecosystem would provide a multitude of ecosystem services.

\section{Conclusions}

In the present study, we estimated the total biomass, carbon storage, as well as the monetary ecosystem service value of the desert riparian P. euphratica in the lower reaches of the Tarim River and found that they were closely associated with water availability. Average total carbon stored by trees within $200 \mathrm{~m}$ distance to the river accounted for $64 \%$ of total estimated carbon, indicating that this area is, or might be, the main pool for carbon storage by riparian forests. This study demonstrated a first estimation of the carbon storage of P. euphratica in the lower reaches of the Tarim River. However, a static view on dynamic ecosystems presents only limited information about the system behavior. To assess the carbon storage dynamics, a chronosequence approach using tree-ring analysis or the analysis of remote sensing time series might be useful. Our study is rather a final statement about the carbon dynamics of the riparian ecosystems at the lower Tarim River, but a first attempt to deliver information for highlighting the relevance of this issue. The results of this study would provide the basis to evaluate the effect of the water diversion by calculating the stored carbon, which, in turn, could be traded as carbon offsets in China's emission trading system.

Acknowledgments: This research work was supported by National Natural Science Foundation of China (grant no: 31700386, U1703102), Doctoral Research Project of the Xinjiang University (grant no: BS160258), the Thousand Youth Talents Plan of China (Xinjiang Projects), the German Federal Ministry of Education and Research (BMBF) within the framework of the SuMaRiO project (01LL0918D), and the German VolkswagenStiftung within the framework of the EcoCAR project (Az.: 88497). We thank the Tarim River Basin Administration Bureau for providing hydrological data and the Forestry Department of Qarkilik (Ruoqiang) for their logistical support during our field work in Arghan. The authors are grateful to the anonymous reviewers for their constructive comments.

Author Contributions: All authors contributed to the design and development of this manuscript. Tayierjiang Aishan carried out the research and prepared the first draft of the manuscript; Florian Betz provided important advice and technical support on the methodology; Ümüt Halik and Bernd Cyffka conceived of and designed the overall concept for the research; data were collected and processed by Tayierjiang Aishan and colleagues from Xinjiang University; and Aihemaitijiang Rouzi was responsible for manuscript proofreading.

Conflicts of Interest: The authors declare no conflict of interest.

\section{References}

1. Intergovernmental Panel on Climate Change (IPCC). IPCC Guidelines for National Greenhouse Gas Inventories, Prepared by the National Greenhouse Gas Inventories Programme; IPCC: Geneva, Switzerland, 2006; Volume 4, ISBN 4-88788-032-4.

2. Fang, J.Y.; Chen, A.P.; Peng, C.H.; Zhao, S.Q.; Ci, L.J. Changes in forest biomass carbon storage in China between 1949 and 1998. Science 2001, 292, 2320-2322. [CrossRef] [PubMed]

3. Piao, S.L.; Fang, J.Y.; Ciais, P.; Peylin, P.; Huang, Y.; Sitch, S.; Wang, T. The carbon balance of terrestrial ecosystems in China. Nature 2009, 458, 1009. [CrossRef] [PubMed]

4. Li, Y.; Wang, Y.G.; Houghton, R.A.; Tang, L.S. Hidden carbon sink beneath desert. Geophys. Res. Lett. 2015, 42, 5880-5887. [CrossRef] 
5. Fahey, T.J.; Woodburry, P.B.; Battles, J.J.; Goodale, J.C.L.; Hamburg, S.P.; Ollinger, S.V.; Wodall, C.W. Forest Carbon Storage: Ecology, Management and Policy. Front. Ecol. Environ. 2010, 8, 245-252. [CrossRef]

6. Pan, Y.; Birdsey, R.S.; Fang, J.; Houghton, R.; Kauppi, P.E.; Kurz, W.A.; Phillips, O.L.; Shvidenko, A.; Lewis, S.L.; Canadell, J.G.; et al. A large and persistent Carbon Sink in the World's Forests. Science 2011, 333, 988-993. [CrossRef] [PubMed]

7. Zerbe, S.; Thevs, N. Restoring Central Asian Floodplain Ecosystems as Natural Capital and Cultural Heritage in a continental Desert Environment. In Landscape Ecology in Asian Cultures; Hong, S.K., Kim, J.E., Wu, J., Nakagoshi, N., Eds.; Ecological Research Monographs; Springer: Tokyo, Japan, 2011; pp. 277-297. ISBN 978-4-431-87798-1.

8. Grünzweig, J.M.; Lin, T.; Rotenberg, E.; Schwartz, A.; Yakir, D. Carbon sequestration in arid-land forest. Glob. Chang. Biol. 2010, 9, 791-799. [CrossRef]

9. Chen, Y.L.; Luo, G.P.; Maisupova, B.; Chen, X.; Mukanov, B.M.; Wu, M.; Mambetov, B.T.; Huang, J.F.; Li, C.F. Carbon budget from forest land use and management in Central Asia during 1961-2010. Agr. For. Meteorol. 2016, 221, 131-141. [CrossRef]

10. Thevs, N.; Buras, A.; Zerbe, S.; Kühnel, E.; Abdusalih, N.; Ovezberdiyeva, A. Structure and wood biomass of near-natural floodplain forests along the Central Asian Rivers Tarim and Amu Darya. Forestry 2012, 85, 193-202. [CrossRef]

11. Buras, A.; Thevs, N.; Zerbe, S.; Wilmking, M. Productivity and carbon sequestration of Populus euphratica at the Amu River, Turkmenistan. Forestry 2013, 86, 429-439. [CrossRef]

12. Kuba, M.; Aishan, T.; Cyffka, B.; Halik, Ü. Analysis of connections between soil moisture, groundwater level and vegetation vitality along two transects at the Lower Reaches of the Tarim River, Northwest China. Geo-Öko 2013, 34, 103-127.

13. Hai, Y.; Wai, L.; Hoppe, T.; Thevs, N. Half a Century of Environmental Change in the Tarim River Valley-An Outline of Cause and Remedies. In Watershed and Floodplain Management along the Tarim River in China's Arid Northwest; Hoppe, T., Kleinschmit, B., Roberts, B., Thevs, N., Halik, U., Eds.; Shaker Press: Aachen, Germany, 2006; pp. 39-76.

14. Song, Y.D.; Fan, Z.L.; Lei, Z.D. Research on Water Resources and Ecology of the Tarim River, China; Peoples Press: Urumqi, China, 2000.

15. Huang, P. Irrigation-Free Vegetation and It's Recovery in Arid Region; Science Press: Beijing, China, 2002; pp. $15-50$.

16. Huang, X.; Chen, Y.N.; Ma, J.X.; Chen, Y.P. Study on change in value of ecosystem service function of Tarim River. Acta Ecol. Sin. 2010, 30, 67-75. [CrossRef]

17. Cyffka, B.; Rumbaur, C.; Kuba, M.; Disse, M. Sustainable Management of River Oases along the Tarim River, P.R. China (SuMaRiO) and the Ecosystem Services Approach. Geogr. Soc. Environ. 2013, 6, 77-90. [CrossRef]

18. Giese, E.; Mamatkanov, D.M.; Wang, R. Wasserressourcen und deren Nutzung im Flussbecken des Tarim (Autonome Region Xinjiang/VR China); Discussion Papers 25.; Zentrum für Internationale Entwicklungsund Umweltforschung: Justus Liebig University Giessen, Germany, 2006; Volume 20, p. 63. Available online: http:/ / geb.uni-giessen.de/geb/volltexte/2006/2661 (accessed on 13 January 2018).

19. Tao, H.; Gemmer, M.; Bai, Y.; Su, B.; Mao, W. Trends of stream flow in the Tarim River Basin through the past 50 years: Human Impact or Climate Change? J. Hydrol. 2011, 400, 1-9. [CrossRef]

20. Aishan, T.; Halik, Ü.; Cyffka, B.; Kuba, M.; Abliz, A.; Baidourela, A. Monitoring the hydrological and ecological response to water diversion in the lower reaches of the Tarim River, northwest China. Quat. Int. 2013, 311, 155-162. [CrossRef]

21. Halik, U.; Kurban, A.; Mijit, M.; Schulz, J.; Paproth, F.; Coenradie, B. The Potential Influence of Embankment Engineering and Ecological Water Transfer on the Riparian Vegetation along the Middle and Lower Reaches of the Tarim River. In Watershed and Floodplain Management along the Tarim River in China's Arid Northwest; Hoppe, T., Kleinschmit, B., Roberts, B., Thevs, N., Halik, U., Eds.; Shaker Press: Aachen, Germany, 2006; pp. 221-236.

22. Chen, Y.N.; Chen, Y.P.; Xu, C.C.; Ye, Z.X.; Li, Z.Q.; Zhu, C.G.; Ma, X.D. Effects of ecological water conveyance on groundwater dynamics and riparian vegetation in the lower reaches of Tarim River, China. Hydrol. Process. 2010, 24, 170-177. [CrossRef]

23. Betz, F.; Halik, Ü.; Kuba, M.; Aishan, T.; Cyffka, B. Controls on aeolian sediment dynamics by natural riparian vegetation in the Eastern Tarim Basin, NW China. Aeolian Res. 2015, 18, 23-34. [CrossRef] 
24. Hoppe, T.; Kleinschmit, B.; Roberts, B.; Thevs, N.; Halik, Ü. Watershed and Floodplain Management along the Tarim River in China's Arid Northwest; Shaker Press: Aachen, Germany, 2006; ISBN 978-3-8322-5662-3.

25. Xu, H.L.; Ye, M.; Li, J.M. The ecological characteristics of the riparian vegetation affected by river overflowing disturbance in the lower Tarim River. Environ. Geol. 2009, 58, 1749-1755. [CrossRef]

26. Chen, Y.N.; Ye, Z.X.; Shen, Y.J. Desiccation of the Tarim River, Xinjiang, China, and mitigation strategy. Quat. Int. 2011, 244, 264-271. [CrossRef]

27. Xu, H.L.; Ye, M.; Li, J.M. Changes in groundwater levels and the response of natural vegetation to transfer of water to the lower reaches of the Tarim River. J. Environ. Sci. 2007, 19, 1199-1207. [CrossRef]

28. Halik, Ü.; Chai, Z.; Kurban, A.; Cyffka, B. The positive response of some ecological indices of Populus euphratica to the emergency water transfer in the lower reaches of the Tarim River. Resour. Sci. 2009, 31, 1309-1314.

29. Halik, Ü.; Aishan, T.; Kurban, A.; Cyffka, B.; Opp, C. Response of Crown Diameter of Populus euphratica to Ecological Water Transfer in the Lower Reaches of Tarim River. J. Northeast For. Univ. 2011, 39, 82-84.

30. Aishan, T.; Halik, Ü.; Kurban, A.; Cyffka, B.; Kuba, M.; Betz, F.; Keyimu, M. Eco-morphological response of floodplain forests (Populus euphratica Oliv.) to water diversion in the lower Tarim River, northwest China. Environ. Earth Sci. 2015, 73, 533-545. [CrossRef]

31. Wu, J.; Tang, D.S. The influence of water conveyances on restoration of vegetation to the lower reaches of Tarim River. Environ. Earth Sci. 2010, 59, 967-975. [CrossRef]

32. Aishan, T. Degraded Tugai Forests under Rehabilitation in the Tarim Riparian Ecosystem, Northwest China: Monitoring, Assessing and Modelling. Ph.D. Thesis, Katholische Universität Eichstätt-Ingolstadt, Eichstätt, Germany, 2016.

33. Chen, B.H.; Li, H.Q. Study on Biomass of natural Diversifolious Poplar Plantations in River Talimu, Xinjiang, Western China. For. Sci. Technol. Xinjiang 1984, 3, 8-16.

34. Thomas, F.M.; Jeschke, M.; Zhang, X.; Lang, P. Stand structure and productivity of Populus euphratica along a gradient of groundwater distances at the Tarim River (NW China). J. Plant Ecol. 2016, 10, 753-764. [CrossRef]

35. Venables, W.N.; Ripley, B.D. Modern Applied Statistics with S; Springer: New York, NY, USA, 2002.

36. Williams, R.A.; Schafer, S.E. Forest Carbon Sequestration and Storage of the Kargasoksky Leshoz of the Tomsk Oblast, Russia-Current Status and the Investment Potential. In Climate Change and Terrestrial Carbon Sequestration in Central Asia; Lal, R., Suleimenov, M., Stewart, B.A., Hansen, D.O., Doraiswamy, P., Eds.; CRC Press: Leiden, The Netherlands, 2007; pp. 363-370. ISBN 9788578110796.

37. Stern, N.H.; Peters, S.; Bakhski, V.; Bowen, A.; Cameron, C.; Catovsky, S.; Crane, D.; Cruickshank, S.; Dietz, S.; Edmondson, N.; et al. Stern Review: The Economics of Climate Change; Cambridge University Press: Cambridge, UK, 2006.

38. Tol, R.S.J. The Economic Effects of Climate Change. J. Econ. Perspect. 2009, 23, 29-51. [CrossRef]

39. Natural Capital Project. Available online: https://www.naturalcapitalproject.org/invest/ (accessed on 20 March 2018).

40. Nordhaus, W.D. A Review of the Stern Review on the Economics of Climate Change. J. Econ. Lit. 2007, 45, 686-702. [CrossRef]

41. Weitzman, M.L. A Review of the Stern Review on the Economics of Climate Change. J. Econ. Lit. 2007, 45, 703-724. [CrossRef]

42. Matzek, V.; Puleston, C.; Gunn, J. Can carbon credits fund riparian forest restoration? Restor. Ecol. 2015, 23, 7-14. [CrossRef]

43. Peng, S.H.; Chen, X.; Qian, J.; Liu, S.G. Spatial Pattern of Populus euphratica Forest Change as Affected by Water Conveyance in the Lower Tarim River. Forests 2014, 5, 134-152. [CrossRef]

44. Luo, Y.J.; Wang, X.K.; Zhang, X.Q.; Lu, F. Biomass and Its Allocation of Forest Ecosystems in China; China Forestry Publishing House: Beijing, China, 2013; pp. 44-45.

45. Schlesinger, W.H.; Belnap, J.; Marion, G. On carbon sequestration in desert ecosystems. Glob. Chang. Biol. 2009, 15, 1488-1490. [CrossRef]

46. Huxman, T.E.; Snyder, K.A.; Tissue, D.; Leffler, A.J.; Ogle, K.; Pockman, W.T.; Sandquist, D.R.; Potts, D.L.; Schwinning, S. Precipitation pulses and carbon fluxes in semiarid and arid ecosystems. Oecologia 2004, 141, 254-268. [CrossRef] [PubMed]

47. Keyimu, M.; Halik, Ü.; Rouzi, A. Relating Water Use to Tree Vitality of Populus euphratica Oliv. in the Lower Tarim River, NW China. Water 2017, 9, 622. [CrossRef] 
48. Keyimu, M.; Halik, Ü.; Kurban, A. Estimation of water consumption of riparian forest in the lower reaches of Tarim River, northwest China. Environ. Earth Sci. 2017, 76, 547. [CrossRef]

49. Thomas, F.M. Ecology of Phreatophytes. In Progress in Botany; Springer: Berlin, Germany, 2014; Volume 75, pp. 335-375. ISBN 978-3-642-38796-8.

50. Hao, X.; Li, W. Impacts of ecological water conveyance on groundwater dynamics and vegetation recovery in the lower reaches of the Tarim River in northwest China. Environ. Monit. Assess. 2014, 186, 7605-7616. [CrossRef] [PubMed]

51. Rumbaur, C.; Thevs, N.; Disse, M.; Ahlheim, M.; Brieden, A.; Cyffka, B.; Duethmann, D.; Feike, T.; Frör, O.; Gärtner, P.; et al. Sustainable management of river oases along the Tarim River (SuMaRiO) in Northwest China under conditions of climate change. Earth Syst. Dyn. 2015, 6, 83-107. [CrossRef]

52. Mamat, Z.; Halik, Ü.; Keyimu, M.; Keram, A.; Nurmamat, K. Variation of the Floodplain Forest Ecosystem Service Value in the Lower Reaches of Tarim River, China. Land Degrad. Dev. 2017, 1-11. [CrossRef]

53. Ma, X.; Feng, Q.; Yu, T.; Su, Y.; Deo, R.C. Carbon dioxide fluxes and their environmental controls in a riparian forest within the hyper-arid region of Northwest China. Forests 2017, 8, 379. [CrossRef]

54. Deng, M.J.; Yang, P.N.; Zhou, H.Y.; Xu, H.L. Water Conversion and Strategy of Ecological Water Conveyance in the Lower Reaches of the Tarim River. Arid Zone Res. 2017, 34, 717-726. [CrossRef]

55. Reyer, C.; Guericke, M.; Ibisch, P.L. Climate change mitigation via afforestation, reforestation and deforestation avoidance: And what about adaptation to environmental change? New For. 2009, 38, $15-34$. [CrossRef]

56. Allen, M.R.; Barros, V.R.; Broome, J.; Cramer, W.; Christ, R.; Church, J.A.; Clarke, L.; Dahe, Q.; Dasgupta, P.; Dubash, N.K.; et al. IPCC Fifth Assessment Synthesis Report-Climate Change 2014 Synthesis Report; World Health Organization: Geneva, Switzerland, 2014; 167p.

57. Lo, A.Y.; Cong, R. After CDM: Domestic carbon offsetting in China. J. Clean. Prod. 2017, 141, 1391-1399. [CrossRef]

(C) 2018 by the authors. Licensee MDPI, Basel, Switzerland. This article is an open access article distributed under the terms and conditions of the Creative Commons Attribution (CC BY) license (http:// creativecommons.org/licenses/by/4.0/). 